of exploration at Grimes' Graves has been continued and Mr. Leslie Armstrong reports on the examination of five pits, one still unfinished, since the date of the last report in 1926. Two communications deal with different aspects of related problems. Of these, one by Mr. Stuart Piggott and Prof. Gordon Childe describes and discusses the affinities of neolithic pottery from Lame, now in the Ashmolean Museum. The authors conclude that in decoration this pottery is a reflex of the current round the north of the British Isles that is supposed to have brought the passage-grave idea to Denmark, while in form it is the most distinctively Iberian in the whole Windmill industry. In the second communication, Mr. J. G. D. Clark examines the distribution of the curved flint sickle blade in Britain, and deriving it from the Nordic culture area, thinks it is to be associated with the Peterborough pottery folk, while it is probable that the Windmill Hill people used a composite sickle. In addition to other communications, there are some useful notes and references.

\section{Barrages on the Niger}

ONE of the most important irrigation schemes in the African Sudan is being carried out in the Upper Senegal district of French West Africa, where the project is to irrigate the Macina district from the flood waters of the Niger. A few details are given in Terre Air Mer for February. At Bamako the Sotuba barrage, 1,340 yards long, irrigates about 15,000 acres on the right bank. The chief barrage, however, is in course of construction below Segu about 200 miles farther downstream at Diamarabougu. This will be about 1,300 yards long and will feed a number of canals on the left of the river. Some of these are already cut and embanked. A navigation canal with locks will be built round this barrage. It is estimated that this irrigation scheme will eventually allow the population of the area affected to be increased fivefold with crops of rice, cotton, forage plants and livestock.

\section{Sir Patrick Geddes}

A supplement issued with the recent number of the Sociological Review (vol. 24, No. 3) consists of tributes to the late Sir Patrick Geddes by friends, former pupils and fellow-workers, in which his manysided genius, his fertility in ideas and his gift for inspiring enthusiasm in others are commemorated. Sir D. M. Stevenson, Lord Provost of Glasgow, writes of "the Social Reformer"; Mr. Edward McGegan, writing from the Outlook Tower, Edinburgh,.with which the name of Geddes will always be associated, speaks of him as a man of action; Lord Sandwich records his part in the saving and re-erection of Crosby Hall; Dr. R. S. Buist tells of his work at University College, Dundee; while intimate views of his enthusiasms, with which he fired others, are given in accounts of his schemes for forming a university students' quarter in London, of his work in town planning in India and in Palestine and his Collège des Ecossais at Montpellier, by writers who were closely associated with him in these undertakings.

\section{Moles Storing Worms}

REFERRING to notes in our Calendar of Nature Topics of Feb. 25, Mr. Lionel E. Adams, Wheatley, Shide Cross, Newport, I.O.W., who contributed a valuable paper entitled "Observations on a Captive Mole" to the Proceedings of the Manchester Literary and Philosophical Society of May 31, 1906, and later, an illustrated article entitled "Moles and Molehills" to NATURE of March 10, 1910, p. 37, writes: "A farmer on whose land I was trapping moles, informed me that while digging out a 'fortress' he came across a mass of dead worms in the nest cavity close to the nest. He described the quantity as 'three spadefuls'. I have frequently watched captive moles bury worms when their hunger was satisfied. The mole would bite the worm with quick bites along its whole length and then cram it into the earth and scratch the earth over it with his fore paws."

\section{Australian Entomology}

Amongst many valuable references to papers in all branches of science, Australian Science Abstracts (No. 4, Nov. 1932) records a "Bibliography of Australian Entornology, 1775-1930", published by the Royal Zoological Society of New South Wales (1932, pp. 1-380). In the list of papers and works touching on Australian insects during that period are references to scientific expeditions which have visited Australia and information concerning authors, collectors and collections. Invaluable to entomologists, the work will be found useful also by zoologists and botanists. An index classifies papers written on various orders of insects, as well as papers on economic, medical and veterinary entomology, and on Australian fossil insects.

\section{The Faraday House Journal}

THE part played by the Faraday House Electrical Engineering College in providing Great Britain with electrical engineers has been a very important one. Its old students are found occupying many of the highest positions in the electrical industry, and the recent issue of the Faraday House Journal states that more than 2,000 students have passed through the College. The virtual founder of the College was Robert Hammond, who in 1882 opened the Hammond Electrical Engineering College. In one of the notes in the Journal reference is made to the attempt to light Cockermouth with electricity in 1881, the opening function being attended by Hammond. That same year Godalming was lighted by electricity, but whereas this proved successful the scheme at Cockermouth failed. The West Cumberland Times, however, looking ahead, said that electricity would revolutionise the world, that the maturing of fruits and vegetables would be speeded up by its use and that the dynamo would be as common on the farm as the threshing machine.

\section{The Ray Society}

AT the annual general meeting of the Ray Society, held on March 22, the following officers were reelected : President, Sir Sidney Harmer; Treasurer, Sir David Prain; Secretary, Dr. W. T. Calman. 